\title{
Reduction of dust deposition in air-cooled condensers in thermal power plants by $\mathrm{Ni}-\mathrm{P}$-based coatings
}

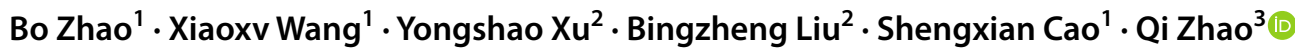

Received: 18 September 2020 / Accepted: 12 February 2021 / Published online: 2 March 2021

(c) The Author(s) 2021

\begin{abstract}
One of the largest problems with most current thermal power plants is the cooling efficiency. This paper aims to massively reduce fuel consumption and heat wasted in thermal power plants and hence $\mathrm{CO}_{2}$ emissions by resolving fouling issues associated with air-cooled condensers. In order to reduce the dust fouling deposition in the air-cooled condensers, the finned flat tubes were coated with nickel-phosphorus and nickel-phosphorus-polytetrafluoroethylene (Ni-P-PTFE) by an electroless coating technology. The anti-fouling performance of the coated tubes was investigated using the field operation parameters of air-cooled condensers, and the influence of the surface energies of the coatings on the dust adhesion was also investigated. The results demonstrated that the $\mathrm{Ni}-\mathrm{P}$ coated finned tubes performed best, which reduced fouling resistance by $83.3 \%$ compared with the untreated finned tubes. The Ni-P coatings have potential applications in thermal power plants for reducing heat exchanger fouling and hence significantly decreasing waste heat and $\mathrm{CO}_{2}$ emissions.
\end{abstract}

\section{Graphic abstract}

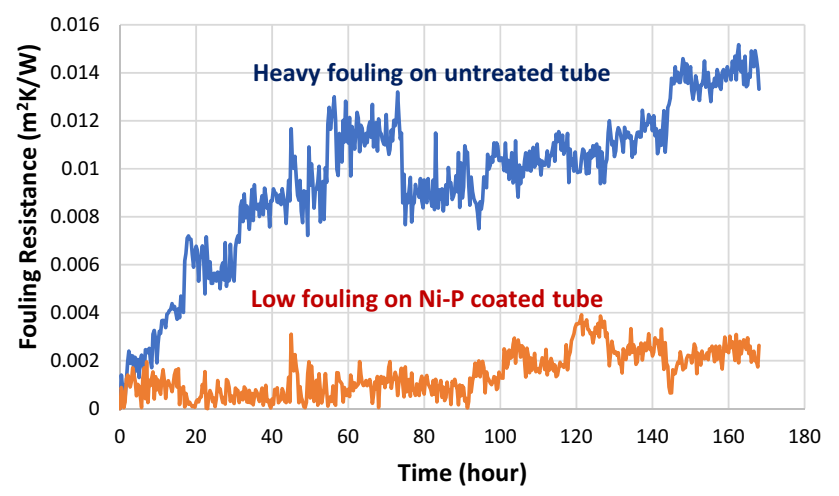

Keywords Thermal power plants $\cdot$ Heat exchanger $\cdot$ Fouling $\cdot$ Dust deposition $\cdot$ Coatings $\cdot \mathrm{CO}_{2}$ emissions

Bo Zhao

zhaobo@neepu.edu.cn

$\triangle$ Qi Zhao

Q.Zhao@dundee.ac.uk

1 School of Automation Engineering, Northeast Electric Power University, Jilin 132012, China

2 China Nuclear Industry Maintenance CO., LTD, Shanghai 201103, China

3 School of Science and Engineering, University of Dundee, Dundee DD1 4HN, UK

\section{Introduction}

Fouling of heat exchangers in processing industries is a chronic operational problem that compromises energy recovery and environmental welfare (Rammerstorfer E et al. 2019). Fouling on the surfaces of heat exchangers acts as a thermal insulator, resulting in significant loss of heat transfer, the increased consumption of fuels and $\mathrm{CO}_{2}$ emissions. Studies have shown that heat exchanger fouling may contribute up to $2.5 \%$ of global $\mathrm{CO}_{2}$ emissions, while reducing the global gross domestic product (GDP) by $0.25 \%$ (Byers 
et al. 2014). Based on 2017 GDP data, heat exchanger fouling costs the UK $\$ 6.5$ billion per year and China $\$ 32$ billion a year. Globally, $80 \%$ of electricity generation comes from thermo-electric power stations using carbonaceous fuels (coal and gas) and nuclear (Casanueva-Robles et al. 2016). The UK electricity mix is dominated by thermo-electric generation capacity which contributes to $90 \%$ of the $~ 380$ TWh generated each year (Byers et al. 2014). The power station sector is responsible for $32 \%$ of the UK's $\mathrm{CO}_{2}$ emissions and has been identified as a key component of the UK's efforts to reduce emissions by $80 \%$ by 2050 , a legally binding target of the Climate Change Act 2008 (Byers et al. 2014). The dielectric barrier discharge plasma reactor has a significant reduction effect on the concentration of carbon dioxide (Abedi-Varaki 2017).

Air-cooled condensers (ACCs) with finned flat tubes are broadly applied in thermal power plant for the purpose of exhaust steam condensation in thermal power plants. However, due to the compact structure of ACCs and the high dust concentration of cooling air, the finned flat tubes are usually prone to fouling on the surfaces of the fin side, as shown in Fig. 1. Dust fouling not only reduces heat transfer coefficient, but also blocks cooling air channel, ultimately resulting in higher energy consumption (Yang et al. 2012). To reduce the influence of fouling on the heat transfer capacity of ACCs, many attempts have been made to improve the efficacy of ACCs. Numerical modelling is usually used to optimize the design of heat exchanger parameters and improve heat exchange efficiency (Lenhard et al. 2019). The optimized design can improve the heat transfer efficiency to a certain extent (Müller-Steinhagen et al. 2007). It is has been demonstrated that the staggered finned tubes can reduce pressure loss and improve heat transfer efficiency (Wu et al. 2012). However, these finned tubes are more prone to fouling due to the small fin spacing (Bell et al. 2011). To accommodate the reduction in heat transfer capacity due to dust fouling, ACCs are generally designed with an excess heat transfer surface area and the finned tubes must be frequently cleaned with high-pressure demineralized water. These countermeasures increase investment costs and the water consumption of power plants in drought areas.

Many attempts have been made to investigate the adhesion mechanisms of dust particles on heat transfer surfaces. $\mathrm{Ni}$ et al. (2018) explained the particle adhesion behavior on the surface of lump coal by the Deryagin, Landau, Verwey and Overbeek (DLVO) theory. They found that the total interaction energy was inversely proportional to the amount of adhered deposit. Zou et al. (2018) used the extended DLVO theory to explore the interfacial interaction between coal and the main impurity mineral particles in application of selective flocculation flotation. It has been shown that in the initial ash deposition stage, the length of the induction period depended on the energy barrier (Zhang et al. 2019).

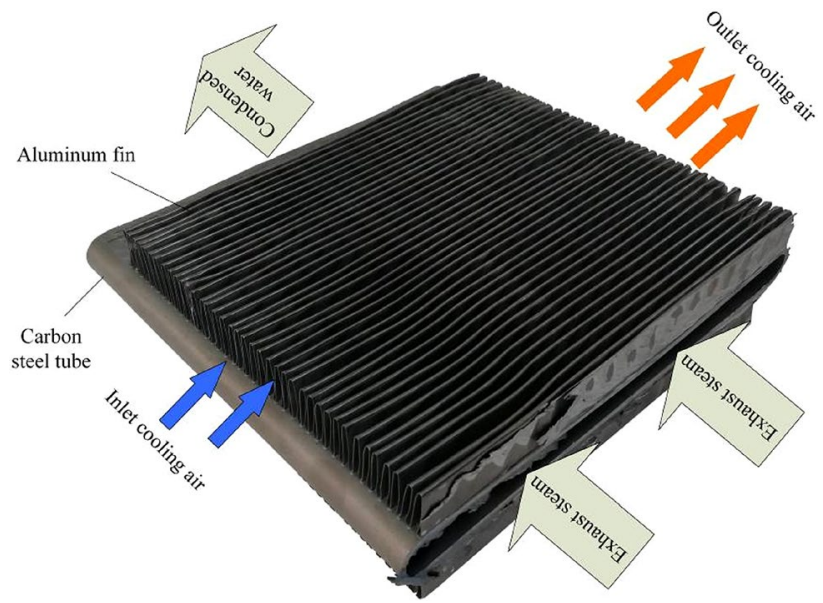

(a) heat transfer process

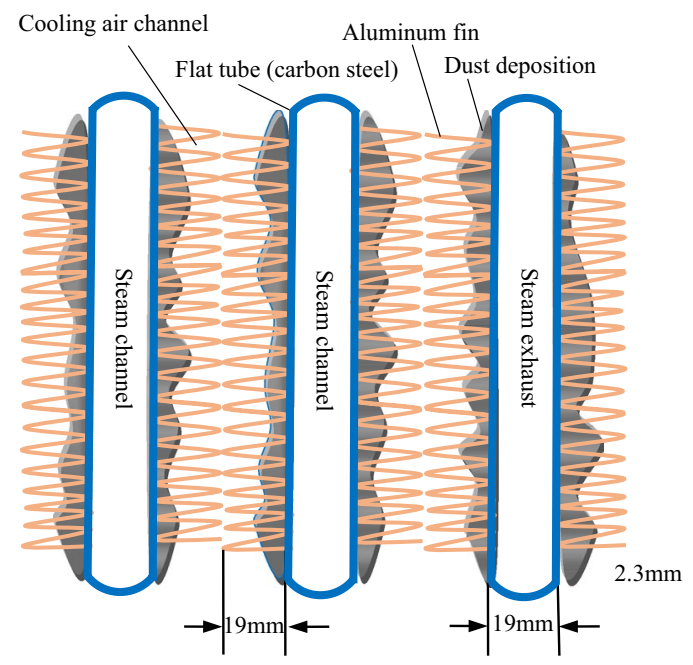

(b) structure parameters

Fig. 1 The finned flat tubes of air-cooled condenser: a heat transfer process; $\mathbf{b}$ structure parameters

The dust particles that are adsorbed on the surface need to cross the energy barrier (Harimawan et al. 2013). During attraction, the electrostatic double-layer force component is the main influencing factor (Liang et al. 2019) and the zeta potential determines the energy barrier level (Yu et al. 2018). Some experimental studies have shown that the surface roughness also affects the energy barrier level (Gungoren et al. 2020), which is the main factor that affects the induction period of the ash deposition process.

It is much more desirable if the surfaces of finned tubes can be modified via a coating with low fouling properties (Zhang et al. 2018). Many attempts have been made to reduce crystalline fouling and biofouling via the application of surface coatings. Cheng et al. (2014) demonstrated 
that the addition of PTFE to the Ni-Cu-P composite coating inhibits mineral fouling accumulation. Zhao et al. (2005) also demonstrated that the Ni-Cu-P-PTFE composite coating inhibits both biofouling and mineral fouling on heat exchanger surfaces. Matjie et al. (2016) demonstrated that the coating with the optimal surface energy minimizes the aluminum silicate deposits. Liu et al. (2011a, b) found that the surface energy components CQ ratio has a strong correlation with fouling adhesion.

The accumulation of dust particles on the surfaces of the finned tubes reduced the efficiency of the heat exchangers. No study has been reported on the reduction of dust fouling with Ni-P coatings. As Ni-P coating is metal based, it has very good thermal conductivity which is similar to steel. The Ni-P-based coating has very good durability and anti-corrosion properties, which is suitable for heat exchange application (Hadzima et al. 2007). However, to the best of the authors' knowledge, there have no applications of Ni-Pbased coatings on the finned tubes to reduce the dust fouling of ACCs. The objective of this paper is to optimize the surface energy of finned flat tubes of ACCs by a Ni-P-based coating technology to mitigate the dust fouling deposition. If successful, it will significantly reduce the waste heat and $\mathrm{CO}_{2}$ emissions of heat exchangers in thermal power plants.

\section{Experimental procedure}

\section{Preparation of coatings on finned flat tube}

To investigate the effect of the surface properties of the coatings on dust fouling adhesion, Ni-P-based composite coatings were prepared on the fin side of the tube bundles (50 mm length $\times 220 \mathrm{~mm}$ width $\times 57 \mathrm{~mm}$ thickness) using an electroless plating technology. The procedures and operation conditions for the electroless $\mathrm{Ni}-\mathrm{P}$ and $\mathrm{Ni}-\mathrm{P}-\mathrm{PTFE}$ composite coatings are listed in Table 1 . The sample needs to be rinsed at room temperature before and after each operation.

The $60 \mathrm{wt} \%$ PTFE emulsion with a particle size in the range of $0.05-0.5 \mu \mathrm{m}$ (purchased from Zhanyang Polymer Materials CO., LTD, Dongguan, China) was diluted with

Table 1 Pretreatment and coating procedures of electroless Ni-P and Ni-P-PTFE coatings

\begin{tabular}{ll}
\hline Procedures & Conditions \\
\hline Alkaline cleaning & $70{ }^{\circ} \mathrm{C}, 2-5 \mathrm{~min}$ \\
Pickling & Room temperature, 5-15 s \\
Electrochemical plating & $\mathrm{DC} 5 \mathrm{~V} ; 0.5 \mathrm{~A}, 2-5 \mathrm{~min}$ \\
Ni-P plating & $88 \mathrm{oC}, \mathrm{pH} 4.8-5.0,80 \mathrm{~min}$ \\
Ni-P-PTFE plating & $88 \mathrm{oC}, \mathrm{pH} 4.8-5.0,80 \mathrm{~min}$ \\
Drying & $120 \mathrm{oC}, 60 \mathrm{~min}$ \\
\hline
\end{tabular}

demineralized water and stirred with a magnetic stirrer for $45 \mathrm{~min}$. During the coating process, the PTFE particles were incorporated into the Ni-P matrix. The compositions and the plating conditions are listed in Table 2. The surface energy of the coatings was changed by changing the concentration of PTFE in the plating solutions. The thickness of the coatings was measured using an X-ray Thickness Gauge. The surface morphology and composition of the coatings were analyzed using a scanning electron microscope (SEM). The thickness of the coatings was controlled by the deposition time.

\section{Experimental system}

For initial screening tests, the air-cooled finned tubes were cut into 50-mm-long segments and then were coated with $\mathrm{Ni}-\mathrm{P}$ and Ni-P-PTFE, respectively. The water circulation circuit consisted of a heating source, circulation pumps and rubber pipes. The hot water originated from the heating tube in the boiler system and the heating source was a $1.5 \mathrm{~kW}$ thermostatic water bath. The water temperature was maintained at $54{ }^{\circ} \mathrm{C}$. The finned tubes were connected to a circulating pump with a power of $160 \mathrm{~W}$. The cooling air driven by an axial flow fan was removed through vertically arranged finned tubes. The wind speed was detected by an air speed sensor installed at the exit of the finned tubes. The fan speed was controlled by a frequency converter to simulate a $2 \mathrm{~m} / \mathrm{s}$ wind speed and generate a $2 \mathrm{~m}^{3} / \mathrm{s}$ volume flow at the operating site. The frequency converter was adjusted to $45 \mathrm{~Hz}$ and could simulate a $2 \mathrm{~m} / \mathrm{s}$ wind

Table 2 Composition and conditions for electroless $\mathrm{Ni}-\mathrm{P}$ and $\mathrm{Ni}-\mathrm{P}-$ PTFE coatings

\begin{tabular}{lllll}
\hline $\begin{array}{l}\text { Composition/ Condi- } \\
\text { tions }\end{array}$ & Alkaline & Pickling & $\mathrm{Ni}-\mathrm{P}$ & $\mathrm{Ni}-\mathrm{P}-\mathrm{PTFE}$ \\
\hline $\mathrm{NiSO}_{4} \cdot 6 \mathrm{H}_{2} \mathrm{O}$ & - & - & $20-35 \mathrm{~g} / \mathrm{L}$ & $20-35 \mathrm{~g} / \mathrm{L}$ \\
$\mathrm{NaH}_{2} \mathrm{PO}_{2} \cdot \mathrm{H}_{2} \mathrm{O}$ & - & - & $20-35 \mathrm{~g} / \mathrm{L}$ & $20-35 \mathrm{~g} / \mathrm{L}$ \\
$\mathrm{Na}_{3} \mathrm{C}_{6} \mathrm{H}_{5} \mathrm{O}_{7} \cdot 2 \mathrm{H}_{2} \mathrm{O}$ & - & - & $10-25 \mathrm{~g} / \mathrm{L}$ & $10-25 \mathrm{~g} / \mathrm{L}$ \\
$\mathrm{C}_{2} \mathrm{H}_{3} \mathrm{NaO}_{2}$ & - & - & $10-25 \mathrm{~g} / \mathrm{L}$ & $10-25 \mathrm{~g} / \mathrm{L}$ \\
$\mathrm{C}_{2} \mathrm{H}_{5} \mathrm{NO}_{2}$ & - & - & $0.1-1 \mathrm{~g} / \mathrm{L}$ & $0.1-1 \mathrm{~g} / \mathrm{L}$ \\
$\mathrm{C}_{3} \mathrm{H}_{6} \mathrm{O}_{3}$ & - & - & $5-10 \mathrm{~g} / \mathrm{L}$ & $5-10 \mathrm{~g} / \mathrm{L}$ \\
$\mathrm{PTFE}(60 \%)$ & - & - & - & $5-25 \mathrm{~mL} / \mathrm{L}$ \\
$\mathrm{CF} 4$ & - & - & - & $0.1-0.4 \mathrm{~g} / \mathrm{L}$ \\
$\mathrm{NaOH}$ & $15-30 \mathrm{~g} / \mathrm{L}$ & - & - & - \\
$\mathrm{Na}_{3} \mathrm{PO}_{4}$ & $20-35 \mathrm{~g} / \mathrm{L}$ & - & - & - \\
$\mathrm{NaCO}_{3}$ & $10-25 \mathrm{~g} / \mathrm{L}$ & - & - & - \\
$\mathrm{Na}_{2} \mathrm{SiO}_{3} \cdot 9 \mathrm{H}_{2} \mathrm{O}$ & $5-10 \mathrm{~g} / \mathrm{L}$ & - & - & - \\
$\mathrm{HCl}(30 \%):$ Water & - & $1: 1$ & - & - \\
$\mathrm{pH}$ & - & - & $4.8-5.0$ & $4.8-5.0$ \\
$\mathrm{Temperature}$ & $70{ }^{\circ} \mathrm{C}$ & Room & $88{ }^{\circ} \mathrm{C}$ & $88{ }^{\circ} \mathrm{C}$ \\
$\mathrm{Time}$ & $2-5 \mathrm{~min}$ & $5-15 \mathrm{~s}$ & $80 \mathrm{~min}$ & $80 \mathrm{~min}$ \\
\hline
\end{tabular}


speed at the outlet. The fan inverter output frequency was fixed to maintain the wind speed. Dust was continuously sprayed above the fan at a rate of $15 \mathrm{mg} / \mathrm{s}$ to maintain the dust concentration at $7.5 \mathrm{mg} / \mathrm{m}^{3}$. K-type thermocouple temperature sensors were installed at the air inlet of the axial flow fan, on the side of the fin tube outlet and on the water inlet and outlet of the fin tubes to measure the wind and water temperatures. The measurements of temperature profiles at different locations are critical for the deposition of ash particles (Jandacka et al. 2017). Temperature data was collected and recorded by a paperless recorder. A computer-controlled data acquisition system regularly read the temperature data. The heat transfer coefficient and thermal resistance were calculated and saved in an Excel table. The experimental system diagram is illustrated in Fig. 2.

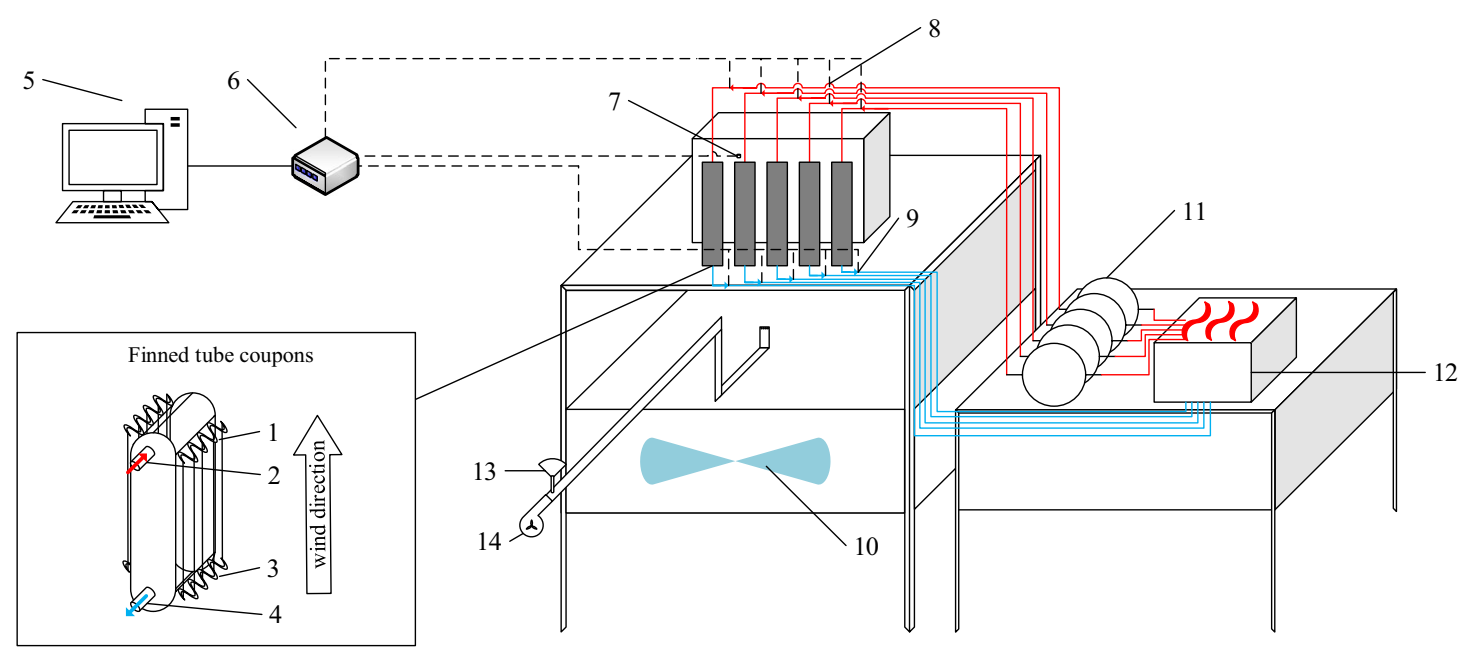

1- Outlet wind; 2- Inlet water; 3- Inlet wind; 4- Outlet water; 5- Computer; 6- Recorder;

7- Anemometer; 8- Thermocouples; 9- Thermocouples; 10- Fan; 11- Circulating Pump;

12- Thermostat water bath; 13- Funnel; 14- Blower

(a) Schematic diagram

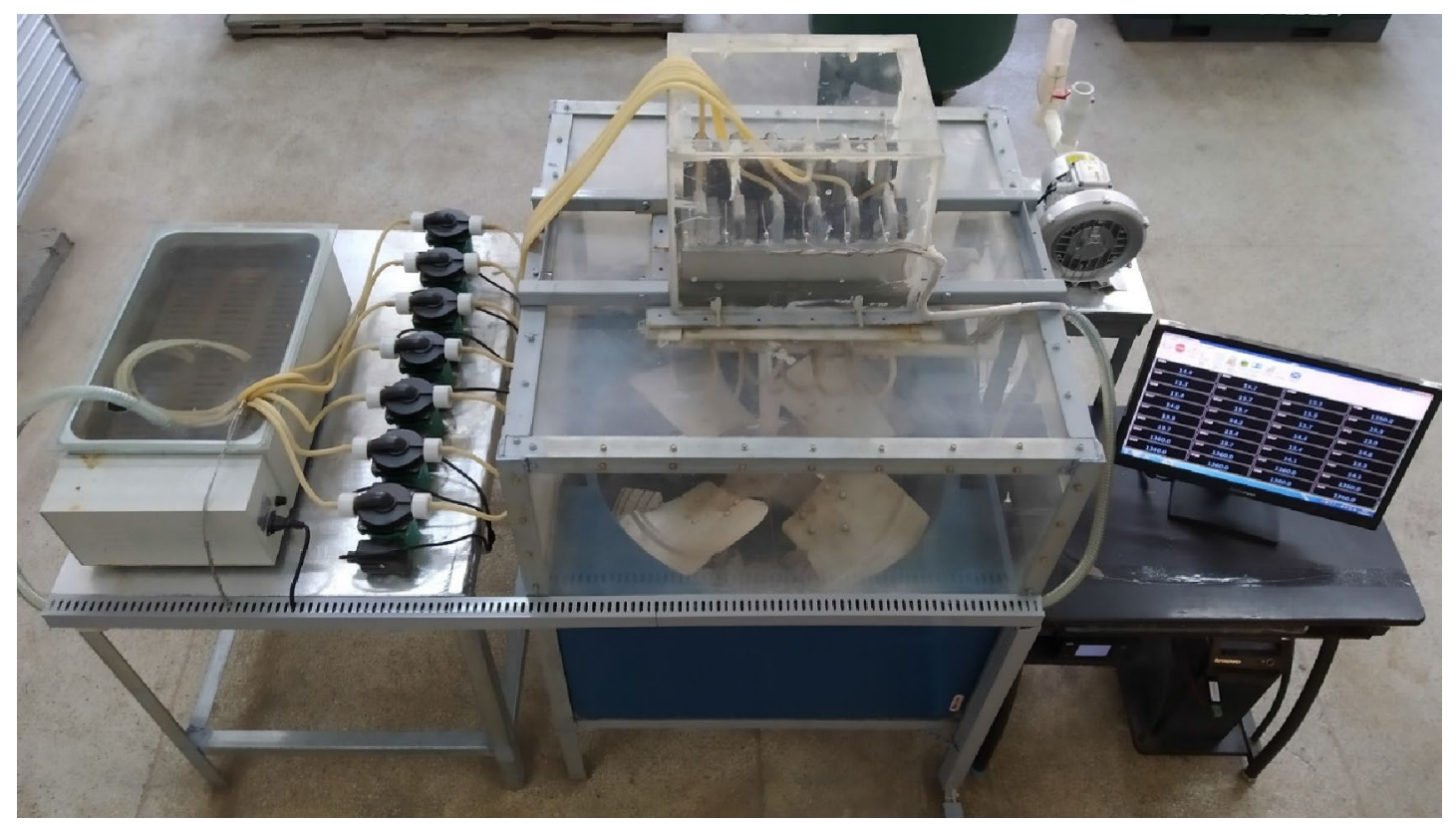

(b) Experimental facilities

Fig. 2 Experimental system: a Schematic diagram; b experimental facilities 


\section{Ash particles}

Because the use of the ash from thermal power plant (the actual area) is not practical, the artificial ash (experimental ash) was used. In order to remove larger fibers, a sieve (100 $\mu \mathrm{m}$ diameter) was used to filter the experimental dust. Energy-dispersive X-ray spectroscopy (EDX) was used for the component and particle size analysis of the dust sample. Figure 3(a) shows the comparison of the main components and proportions of the ash from a local thermal power plant with the artificial ash. There were no significant differences in the components and proportions between the two types of ash. The average particle size of the ash from the actual area was around $15 \mu \mathrm{m}$, and the average size of experimental ash particles was also around $15 \mu \mathrm{m}$, as shown in Fig. 3(b). Laser particle size analyzer (TopSizer, OMEC CO., LTD, Zhuhai, China) was used to measure the size of ash particles.

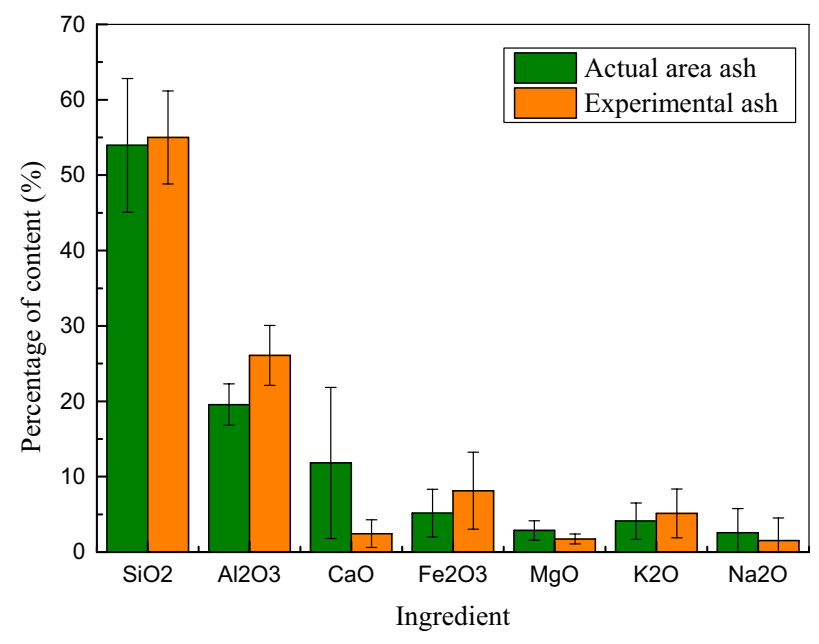

(a) Ash components

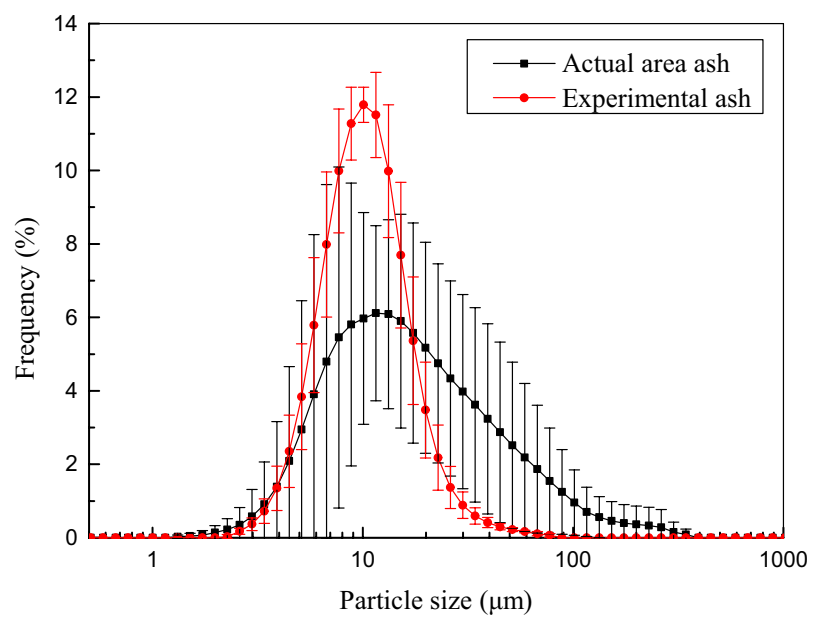

(b) Ash particle sizes

Fig. 3 a Ash components; $\mathbf{b}$ ash particle sizes

\section{Analysis method}

The air-cooler heat transfer coefficient was calculated according to the heat balance theory (Liu et al. 2013). When an air cooler is operated for a period of time, dust accumulates on the surfaces of the finned tubes to cause ash accumulation. The definitions of the heat transfer coefficient and the fouling resistance as well as their analysis methods are described in detail by Tang et al. (2019) and Wang et al. (2019).

\section{Results and discussion}

\section{Surface analysis of coatings}

Figure 4 shows the surface morphologies of the untreated and treated aluminum finned tubes. Figure $4 \mathrm{a}$ shows the SEM image of an untreated aluminum finned tube. Figure $4 \mathrm{~b}$ is the SEM image of a typical Ni-P coated finned tube, which is much smoother than the untreated finned tube. Figure $4 \mathrm{c}-\mathrm{f}$ show the SEM images of Ni-PPTFE coated finned tubes with PTFE contents 9.2\%, 11.4\%, $21.9 \%$ and $23.9 \%$, respectively. The surface roughness increased slightly with increasing PTFE content.

Figure 5 shows the chemical compositions of the coatings by EDX analysis. The F element in Fig. 5(c-f) was from the PTFE particles in the Ni-P-PTFE coatings. Since the chemical formula of PTFE is - $\left(\mathrm{CF}_{2}-\mathrm{CF}_{2}\right)_{\mathrm{n}}$, , the corresponding PTFE contents in the Ni-P-PTFE coatings were calculated based on the F contents and the PTFE formula, which was $9.2 \%, 11.4 \%, 21.9 \%$ and $23.9 \%$, respectively. The PTFE contents in the Ni-P-PTFE coatings increased with increasing PTFE concentration in the plating solution.

Table 3 shows the thickness of the coatings, which is in the range of $4 \mu \mathrm{m} \sim 14.5 \mu \mathrm{m}$ (measured by X-ray Thickness Gauge). The thickness of the aluminum fins was $444 \mu \mathrm{m}$. As the thickness of the coatings was very thin and the coatings mainly contained metal Ni-P, the additional thermal resistance of the coatings should be negligible. To verify this idea, the thermal resistance of the coatings was measured. The results indicated that the additional thermal resistance of the coatings was only increased by $0.071 \%$ $~ 0.32 \%$, which is indeed negligible.

The contact angles on the coatings were determined using a sessile drop technique with a contact angle instrument with a resolution of $0.5^{\circ}$. The four test liquids, including distilled water, diiodomethane, ethylene glycol and glycerol, were used for the contact angle measurements (Han et al. 2019). For each test liquid, 10 measurements were performed and an average value of the 10 contact angles on the coating was obtained. 


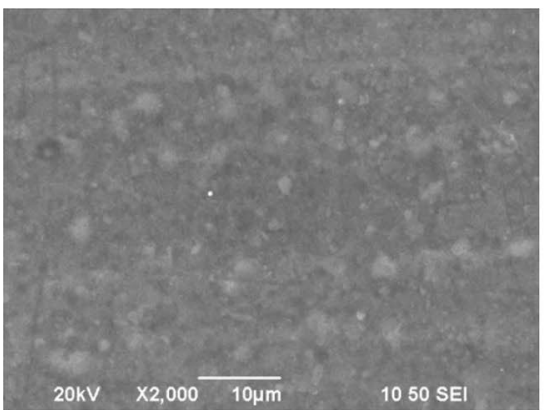

(a) Untreated aluminum tube

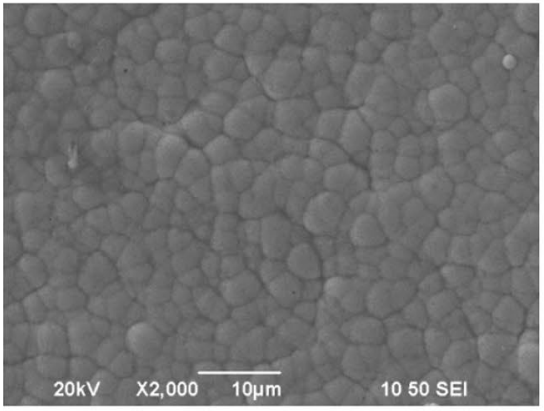

(d) Ni-P-PTFE (11.4\%) coated tube

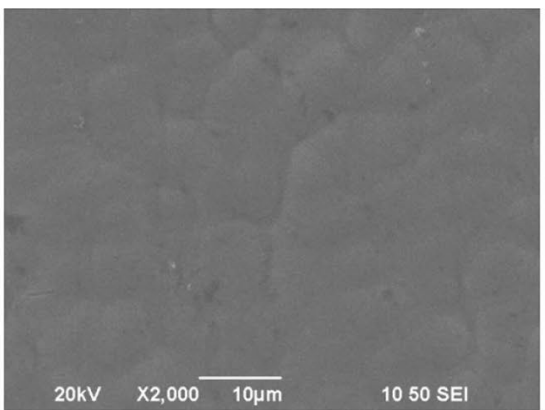

(b) Ni-P coated tube

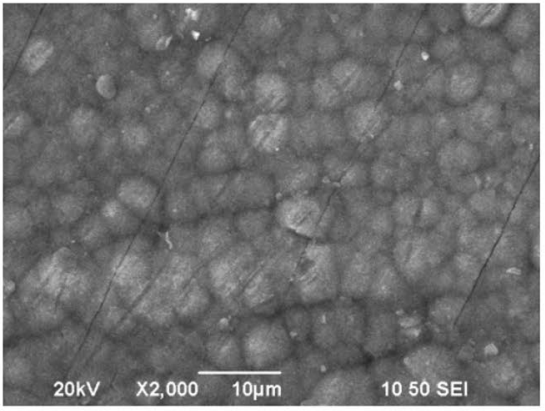

(e) Ni-P-PTFE (21.9\%) coated tube

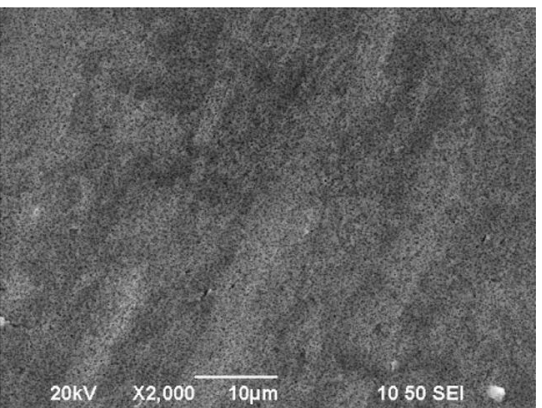

(c) Ni-P-PTFE (9.2\%) coated tube

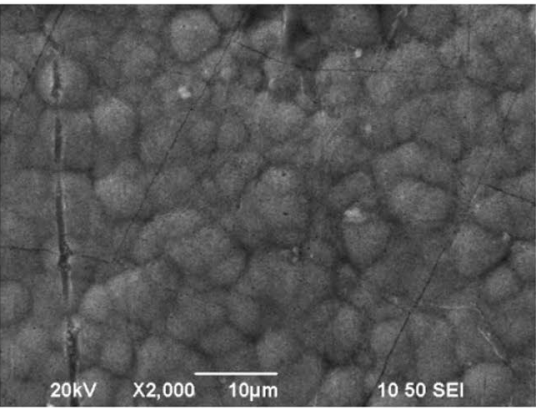

(f) Ni-P-PTFE (23.9\%) coated tube

Fig. 4 SEM images of untreated and coated finned tubes

Table 4 lists the contact values and surface energy components of the Ni-P coated tube, Ni-P-PTFE coated tubes with different PTFE contents, untreated aluminum tube and dust particles. In the table, the $\gamma^{L W}, \gamma^{A B}, \gamma^{+}$and $\gamma^{-}$are Lifshitzvan de Waals (LW), acid-base (AB), electron-accepter and electron-donator components of surface energy, respectively, and $\gamma^{T O T}$ is the total surface energy. Clearly the total surface energy of the Ni-P-PTFE coatings decreased with PTFE content increasing.

\section{Dust fouling characteristics}

After $168 \mathrm{~h}$ of ash deposition, the heat transfer coefficient and thermal resistance (also known as fouling resistance) were determined, respectively, by measuring the water temperatures and air temperatures at the inlet and the outlet. The heat transfer coefficient and thermal resistance of each coating are presented in Figs. 6 and 7, respectively. Figure 6 clearly indicates that all the coated finned tubes had much higher heat transfer coefficients than the uncoated finned tube. The Ni-P coated finned tubes performed best in inhibiting ash deposition and the heat transfer coefficient was only decreased slightly after $168 \mathrm{~h}$ operation, while the heat transfer coefficient of the untreated finned tubes was decreased sharply. The Ni-P coated finned tubes performed better than the Ni-P-PTFE coated tubes in the reduction of the ash accumulation, as the PTFE particles made the Ni-P-PTFE coating rougher. Figure 7 shows the comparison of fouling resistance of the Ni-P coated finned tubes with the untreated finned tubes. The fouling resistance of the untreated finned tubes increased rapidly to $0.015 \mathrm{~m}^{2} \mathrm{~K} / \mathrm{W}$ after $168 \mathrm{~h}$ operation, while the fouling resistance of the Ni-P coated finned tubes only increased to $0.0025 \mathrm{~m}^{2} \mathrm{~K} / \mathrm{W}$, which was decreased by $83.3 \%$ as compared with the untreated finned tubes.

\section{Discussion}

\section{Waste heat and $\mathrm{CO}_{2}$ emissions}

As carbon dioxide $\left(\mathrm{CO}_{2}\right)$ is the primary greenhouse gas, this work focused on the improvement of the greenhouse effect by energy saving. Currently several techniques are available for reducing $\mathrm{CO}_{2}$ emissions. The turning of food waste into biogas via anaerobic fermentation is widely recognized as an environmentally responsible and economically reasonable option (Marouek et al. 2020). Solid biofuels also have the characteristics of reducing carbon dioxide emissions (Mardoyan et al. 2015). Biowaste collection and circular economy are closely related (Rolewicz-Kalińska et al. 2020). Meanwhile, fouling deposits on the surface of condensers/heat exchangers have a severe impact on the condenser's ability to condense the exhaust steam, resulting in a significant increase in the amount of fuel 


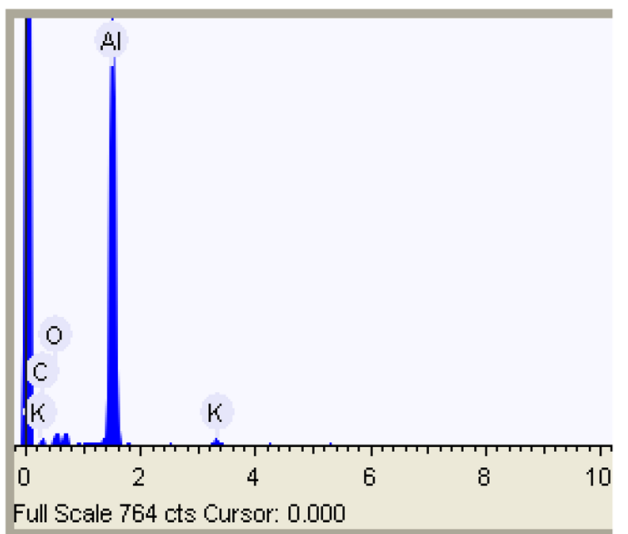

(a) Aluminum oxide

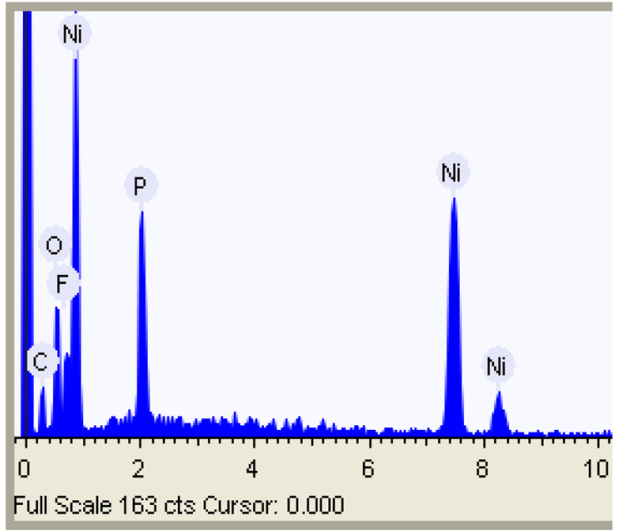

(c) Ni-P-PTFE $(9.2 \%)$

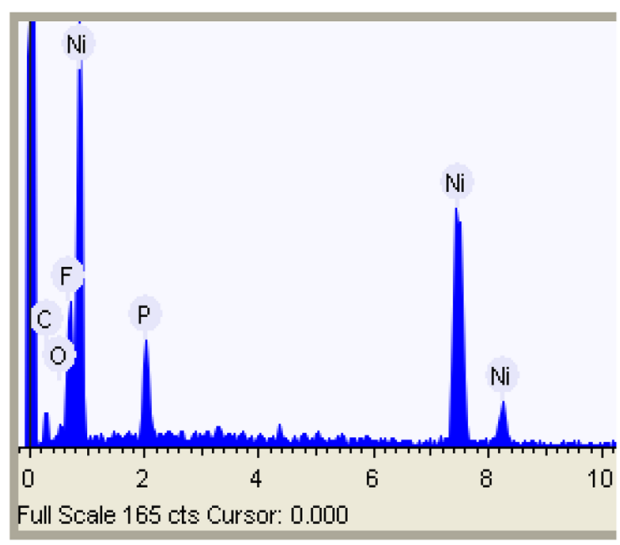

(e) Ni-P-PTFE $(21.9 \%)$

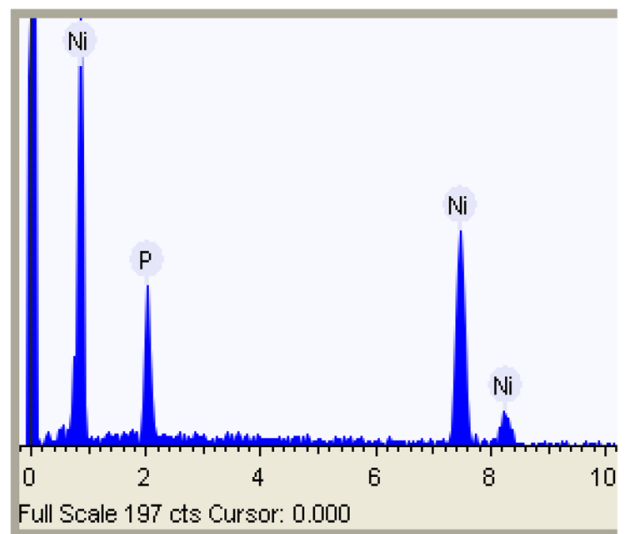

(b) Ni-P

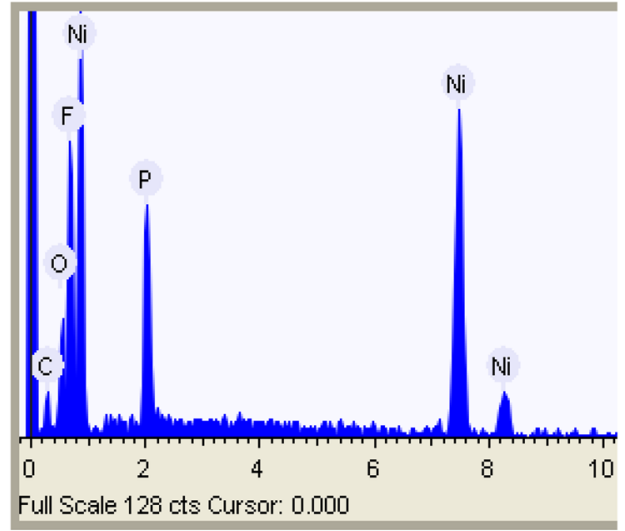

(d) Ni-P-PTFE (11.4\%)

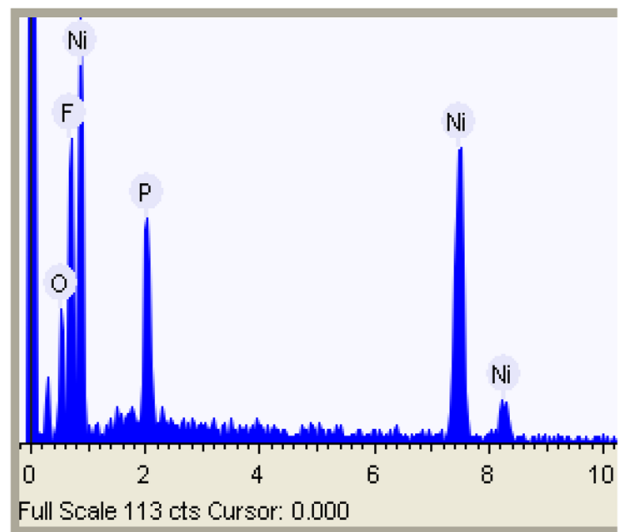

(f) Ni-P-PTFE (23.9\%)

Fig. 5 EDX spectra of untreated and coated finned tubes

consumption, waste energy and $\mathrm{CO}_{2}$ emissions (Byers et al. 2014). It has been demonstrated that for a $550 \mathrm{MW}$ coal-fired power station, a thin layer of fouling film $(0.5 \mathrm{~mm})$ on heat transfer surfaces in power station steam condensers can increase waste heat by $6.3 \times 10^{10} \mathrm{~kJ} / \mathrm{y}$ and $\mathrm{CO}_{2}$ emissions by $13,728 \mathrm{t} / \mathrm{y}$ (Casanueva-Robles et al. 2016).
Recently several coal-fired power stations closed due to approaching the end of their original design life and $\mathrm{CO}_{2}$ emissions. China electricity mix is dominated by coal-fired generation capacity (3906 TWh) which contributes to $65 \%$ of the total $5983 \mathrm{TWh}$ generated each year. The formation of a $0.5-\mathrm{mm}$-thick fouling film on the steam condensers in these coal-fired power stations in China can increase waste 
Table 3 Characterization of coatings

\begin{tabular}{|c|c|c|c|c|c|c|}
\hline Coatings & Finned flat tube & $\mathrm{Ni}-\mathrm{P}$ & $\begin{array}{l}\text { Ni-P-PTFE } \\
(9.2 \%)\end{array}$ & Ni-P-PTFE (11.4\%) & $\begin{array}{l}\text { Ni-P-PTFE } \\
(21.9 \%)\end{array}$ & $\begin{array}{l}\text { Ni-P-PTFE } \\
(23.9 \%)\end{array}$ \\
\hline $\begin{array}{l}\text { Heat conductivity Coefficient } \\
\left(\mathrm{W} \mathrm{m}^{-1} \mathrm{~K}^{-1}\right)\end{array}$ & - & 165.049 & 152.135 & 149.816 & 142.736 & 132.551 \\
\hline Coating thickness $(\mu \mathrm{m})$ & 500 & 4 & 8 & 10 & 13 & 14.5 \\
\hline Heat transfer resistance $\left(\mathrm{m}^{2} \mathrm{~K} \mathrm{~W}^{-1}\right)$ & 0.042 & 0.000024 & 0.000053 & 0.000067 & 0.000091 & 0.00011 \\
\hline Increased thermal resistance $(\%)$ & - & $0.071 \%$ o & $0.15 \%$ & $0.20 \%$ & $0.27 \%$ & $0.32 \%$ \\
\hline
\end{tabular}

Table 4 Contact angle and surface energy components

\begin{tabular}{|c|c|c|c|c|c|c|c|c|c|c|c|}
\hline \multicolumn{2}{|c|}{ Coatings } & \multicolumn{4}{|c|}{ Contact angle $\theta\left(^{\circ}\right)$} & \multicolumn{6}{|c|}{ Surface energy $\left(\mathrm{mJ} / \mathrm{m}^{2}\right)$} \\
\hline Name & Chemistry & $\theta^{W}$ & $\theta^{D}$ & $\theta^{E}$ & $\theta^{\mathrm{G}}$ & $\gamma^{L W}$ & $\gamma^{A B}$ & $\gamma^{+}$ & $\gamma^{-}$ & $\gamma^{T O T}$ & $\begin{array}{l}1 / \mathrm{CQ} \\
\gamma^{-} / \gamma^{L W}\end{array}$ \\
\hline 1 & $\mathrm{Ni}-\mathrm{P}$ & 62.2 & 43.4 & 42.6 & - & 29.7 & 15.4 & 1.53 & 36.36 & 45.15 & 1.22 \\
\hline 2 & Ni-P-PTFE(9.2\%) & 68.8 & 49.6 & 40.2 & - & 28.3 & 10.0 & 1.03 & 24.26 & 38.34 & 0.86 \\
\hline 3 & Ni-P-PTFE(11.4\%) & 88.4 & 33.3 & 59.8 & - & 30.3 & 2.2 & 0.26 & 4.52 & 32.5 & 0.15 \\
\hline 5 & Ni-P-PTFE(21.9\%) & 81.6 & 35.3 & 74.5 & - & 18.6 & 2.7 & 0.28 & 6.66 & 21.38 & 0.36 \\
\hline 4 & Ni-P-PTFE(23.9\%) & 72.9 & 38.5 & 78.7 & - & 13.9 & 4.0 & 0.41 & 9.56 & 17.88 & 0.69 \\
\hline 6 & $\begin{array}{l}\text { Aluminum oxide } \\
\text { (Fin of ACC) }\end{array}$ & 73.9 & 39.5 & 61.8 & & 34.6 & 0.04 & 2.91 & 0 & 34.64 & 0 \\
\hline 7 & Dust & _- & 34.8 & 24.0 & 33.7 & 35.3 & 10.4 & 4.94 & 5.48 & 45.71 & - \\
\hline
\end{tabular}
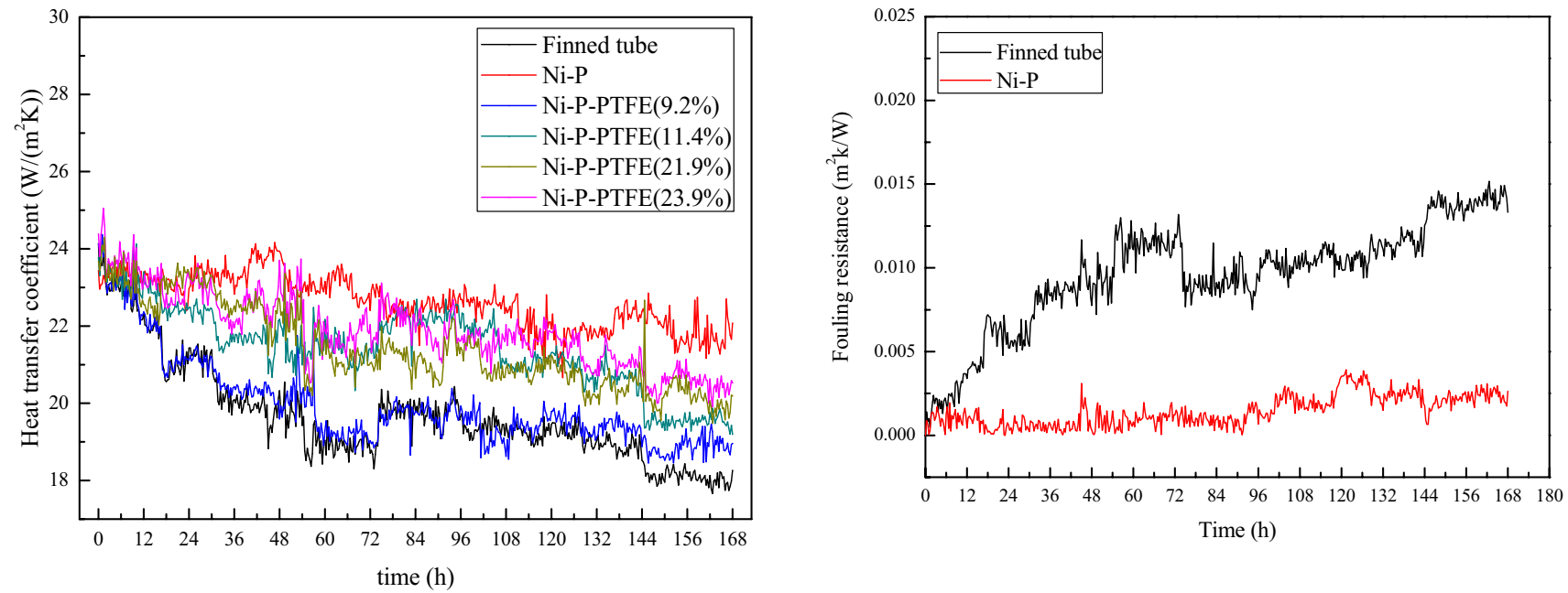

Fig. 7 Fouling resistance vs time

Fig. 6 Heat transfer coefficient vs time

heat by $4.5 \times 10^{17} \mathrm{~kJ} / \mathrm{y}$ and $\mathrm{CO}_{2}$ emissions by 99 billion $\mathrm{t} / \mathrm{y}$, based on Casanueva-Robles and Bott's calculation method (Casanueva-Robles et al. 2016). The experimental results in this study demonstrated that the Ni-P coated finned tubes reduced fouling resistance by $83.3 \%$ compared with the untreated finned tubes. The cost due to ash accumulation is defined as the operating economic loss caused by the increase in the exhaust pressure of the unit. Due to the increased thermal resistance by ash accumulation, the exhaust pressure of the steam turbine increases and the output power of the generator set decreases. Application of the $\mathrm{Ni}-\mathrm{P}$ anti-fouling coatings to heat exchangers in thermal power plants will significantly decrease waste heat and $\mathrm{CO}_{2}$ emissions.

\section{Surface energy and Fouling adhesion} decreased due to ash fouling formation on the tubes.
After 168-h operation, the heat transfer coefficient 


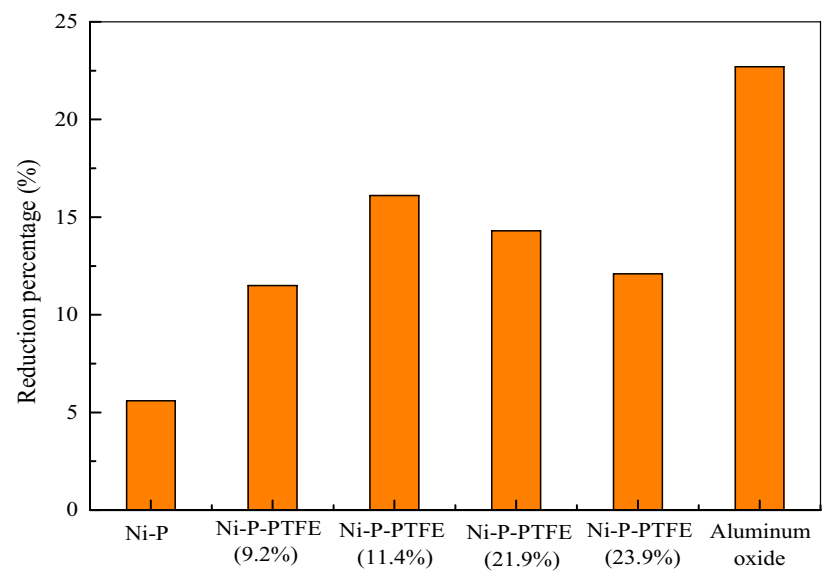

Fig. 8 Comparison of the reduction percentage in heat transfer coefficient of the coated finned tubes with the untreated finned tubes

Figure 8 shows the comparison of the reduction percentage in heat transfer coefficient of the coated finned tubes with the untreated finned tubes. Clearly, all the coated tubes have lower reduction percentage in heat transfer coefficient, compared with the untreated tube. Ni-P coated tube has the lowest reduction percentage and the untreated tube has the highest reduction percentage.

It is well know that the surface energy components, especially the Lifshitz-van der Waals component $\left(\gamma^{L W}\right)$ and electron-donator component $\left(\gamma^{-}\right)$, have significant influence on fouling adhesion. Chen Liu and Qi Zhao found that the ratio $\gamma^{L W} / \gamma^{-}$(called as CQ ratio, which is named after the authors, Chen and Qi) determines fouling adhesion strength (Liu et al. 2011a, b) In this investigation, the surface energy components $\left(\gamma^{L W}\right.$ and $\left.\gamma^{-}\right)$of the untreated aluminum fins were $34.6 \mathrm{~mJ} / \mathrm{m}^{2}$ and $0 \mathrm{~mJ} / \mathrm{m}^{2}$, respectively (see Table 4). After coating with Ni-P and Ni-P-PTFE, the $\gamma^{L W}$ and $\gamma^{-}$values changed in wide range, in the ranges of $13.9-30.3 \mathrm{~mJ} / \mathrm{m}^{2}$ and $4.5-36.4 \mathrm{~mJ} / \mathrm{m}^{2}$, respectively (see Table 4). However, the surface energy component $\gamma_{2}^{+}$value was nearly equal to zero, in the narrow range of $0.26-1.5 \mathrm{~mJ} / \mathrm{m}^{2}$. In order to explain Fig. 8, we correlated the reduction percentage in heat transfer coefficient with the new ratio $\gamma^{-} / \gamma^{L W}(1 / \mathrm{CQ})$. The 1/CQ ratio for the coated finned tubes and the untreated finned tube is given in Table 4. Figure 9 indicates that the reduction percentage in heat transfer coefficient has a strong correlation with 1/ CQ ratio, that is, the reduction percentage decreases linearly with $1 / C Q$ ratio increasing. The results will help to design anti-fouling coatings by optimum surface energy approach through surface modification. This study did not consider the effect of surface roughness on dust deposition. This will be our next stage of work. The joint study of surface energy components and surface roughness will help us to understand the mechanism of dust deposition.

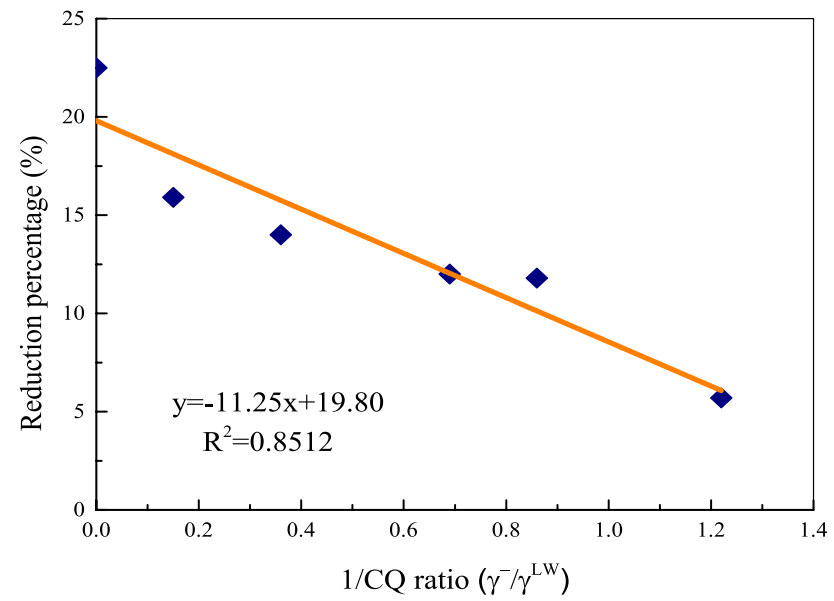

Fig. 9 Influence of $1 / \mathrm{CQ}$ ratio on reduction percentage in heat transfer coefficient

\section{Conclusion}

In this study, Ni-P and Ni-P-PTFE were applied to the coupons of finned tubes to investigate their effects on the anti-fouling performance. The Ni-P coated finned tubes performed best, which reduced fouling resistance by $83.3 \%$ compared with the untreated finned tubes. Both the Lifshitzvan der Waals (LW) component and electron-donator component of surface energy have significant influence on fouling adhesion. The ratio of electron-donator component to LW component (1/CQ ratio) controls the dust fouling formation and adhesion. The reduction percentage in heat transfer coefficient decreases linearly with 1/CQ ratio increasing. The Ni-P anti-fouling coatings have protentional application to heat exchangers in thermal power plants, which can significantly decrease waste heat and $\mathrm{CO}_{2}$ emissions.

Acknowledgements This work was supported by the Science and Technology Development Plan of Jilin Province (Grant No. 20190201098JC).

\section{Compliance with Ethical Standards}

Conflicts of interest The authors declare that there is no conflict of interest.

Open Access This article is licensed under a Creative Commons Attribution 4.0 International License, which permits use, sharing, adaptation, distribution and reproduction in any medium or format, as long as you give appropriate credit to the original author(s) and the source, provide a link to the Creative Commons licence, and indicate if changes were made. The images or other third party material in this article are included in the article's Creative Commons licence, unless indicated otherwise in a credit line to the material. If material is not included in the article's Creative Commons licence and your intended use is not permitted by statutory regulation or exceeds the permitted use, you will need to obtain permission directly from the copyright holder. To view a copy of this licence, visit http://creativecommons.org/licenses/by/4.0/. 


\section{References}

Abedi-Varaki M (2017) Study of carbon dioxide gas treatment based on equations of kinetics in plasma discharge reactor. Mod Phys Lett B 31(22): 1750210

Bell IH, Groll EA (2011) Air-side particulate fouling of microchannel heat exchangers: Experimental comparison of air-side pressure drop and heat transfer with plate-fin heat exchanger. Appl Therm Eng 31(5):742-749

Byers EA, Hall JW, Amezagaa JM (2014) Electricity generation and cooling water use: UK pathways to 2050. Global Environ Chang 25:16-30

Casanueva-Robles T, Bott TR (2016) Proceedings of 6th International Conference on Heat Exchanger Fouling and Cleaning. The Berkeley Electronic Press. 2; 278-282.

Cheng YH, Chen HY, Zhu ZC, Jen TC, Peng YX (2014) Experimental study on the anti-fouling effects of Ni-Cu-P-PTFE deposit surface of heat exchangers. Appl Therm Eng 68:20-25

Gungoren C, Guven O, Cinar M, Ozdemir O (2020) An investigation of the effect of clay type on coal flotation along with DLVO theoretical analyses. Int J Coal Prep Util 40(3):210-222

Hadzima B, Janecek M, Estrin Y, Kim HS (2007) Microstructure and corrosion properties of ultrafine-grained interstitial free steel. Mat Sci Eng A 462(1-2):243-247

Han B, Liang S, Wang B, Zheng J, Xie X, Xiao K, Wang X, Huang X (2019) Simultaneous determination of surface energy and roughness of dense membranes by a modified contact angle method. Colloid Surface A 562:370-376

Harimawan A, Zhong S, Lim CT, Ting TP (2013) Adhesion of B. subtilis spores and vegetative cells onto stainless steel-DLVO theories and AFM spectroscopy. J Colloid Interf Sci 405:233-241

Jandacka J, Micieta J, Holubcik M, Nosek R (2017) Experimental Determination of Bed Temperatures during Wood Pellet Combustion. Energ Fuel 31(3):2919-2926

Lenhard R, Malcho M, Jandačka J (2019) Modelling of Heat Transfer in the Evaporator and Condenser of the Working Fluid in the Heat Pipe. Heat Transfer Eng 40(3-4):215-226

Liang L, Tan J, Li B, Xie G (2019) Reducing quartz entrainment in fine coal flotation by polyaluminum chloride. Fuel 235:150-157

Liu C, Zhao Q (2011a) Influence of surface-energy components of Ni-P-TiO 2 -PTFE nanocomposite coatings on bacterial adhesion. Langmuir 27:9512-9519

Liu C, Zhao Q (2011b) The CQ ratio of surface energy components influences adhesion and removal of fouling bacteria. Biofouling 27:275-285

Liu J, Hu Y, Zeng D, Wang W (2013) Optimization of an air-cooling system and its application to grid stability. Appl Therm Eng 61:206-212

Mardoyan A, Braun P (2015) Analysis of Czech Subsidies for Solid Biofuels. Int J Green Energy 12(4):405-408

Marouek J, Struneck O, Kolá L, Vochozka M (2020) Advances in nutrient management make it possible to accelerate biogas production and thus improve the economy of food waste processing. Energ Source Part A 2:1-10
Matjie R, Zhang S, Zhao Q, Mabuza N, Bunt JR (2016) Tailored surface energy of stainless steel plate coupons to reduce the adhesion of aluminium silicate deposit. Fuel 181:573-578

Müller-Steinhagen H, Malayeri MR, Watkinson AP (2007) Recent Advances in Heat Exchanger Fouling Research, Mitigation and Cleaning Techniques. Heat Transfer Eng 28:173-176

Müller-Steinhagen H, Malayeri MR, Watkinson AP (2011) Heat Exchanger Fouling: Environmental Impacts. Heat Transfer Eng 30:773-776

Ni C, Bu X, Xia W, Peng Y, Yu H, Xie G (2018) Observing slimecoating of fine minerals on the lump coal surface using particle vision and measurement. Powder Technol 339:434-439

Rammerstorfer E, Karner T, Siebenhofer M (2019) The kinetics and mechanisms of fouling in crude oil heat transfer. Heat Transfer Eng 41(2):1-17

Rolewicz-Kalińska A, Lelicińska-Serafin K, Manczarski P (2020) The Circular Economy and Organic Fraction of Municipal Solid Waste Recycling Strategies. Energies 13(17):4366

Tang SZ, Li MJ, Wang FL, Liu ZB (2019) Fouling and thermal-hydraulic characteristics of aligned elliptical tube and honeycomb circular tube in flue gas heat exchangers. Fuel 251:316-327

Wang FL, Tang SZ, He YL, Kulacki FA, Yu Y (2019) Heat transfer and fouling performance of finned tube heat exchangers: Experimentation via on line monitoring. Fuel 236:949-959

Wu JM, Zhang H, Yan CH, Wang Y (2012) Experimental study on the performance of a novel fin-tube air heat exchanger with punched longitudinal vortex generator. Energ Convers Manage 57:42-48

Yang L, Tan H, Du X, Yang Y (2012) Thermal-flow characteristics of the new wave-finned flat tube bundles in air-cooled condensers. Int J Therm Sci 53:166-174

Yu Y, Ma L, Xu H, Sun X, Zhang Z, Ye G (2018) DLVO theoretical analyses between montmorillonite and fine coal under different $\mathrm{pH}$ and divalent cations. Powder Technol 330:147-151

Zhang C, Zhong L, Wang J (2018) Decoupling between water use and thermoelectric power generation growth in China. Nat Energy 3:792-799

Zhang XY, Zhou XT, Xi HP, Sun JX, Liang XL, Wei J, Xiao X, Liu ZG, Li SW, Liang ZS, Chen YY, Wu ZR (2019) Interpretation of adhesion behaviors between bacteria and modified basalt fiber by surface thermodynamics and extended DLVO theory. Colloid Surface B 177:454-461

Zhao Q, Liu Y, Wang S, Müller-Steinhagen H (2005) Effect of surface free energy on the adhesion of biofouling and crystalline fouling. Chem Eng Sci 60(17):4858-4865

Zou W, Zhao J, Sun C (2018) Adsorption of Anionic Polyacrylamide onto Coal and Kaolinite Calculated from the Extended DLVO Theory Using the van Oss-Chaudhury-Good Theory. PolymersBasel 10(2):113

Publisher's Note Springer Nature remains neutral with regard to jurisdictional claims in published maps and institutional affiliations. 